штучної вентиляції легень (ШВЛ) через інтубаційну трубку, отже, і пов'язаних з ними ускладнень. Вивчали ефективність та показання до використання НІВЛ у хворих з онкологічними захворюваннями, які перенесли оперативні втручання на органах грудної клітки. У період 3 2013 р. було досліджено 34 пацієнти, які перенесли операцію на органах грудної клітки. Пацієнтів було розподілено на дві групи. В І групу включено пацієнтів $(n=24)$, яким в ранньому післяопераційному періоді проводили НІВЛ; в ІІ - пацієнтів $(n=10)$, ведення яких проводили згідно з локальним протоколом. Застосування НІВЛ у хворих, оперованих на органах грудної клітки, було ефективним, оскільки покращались показники гемодинаміки і газового складу крові, що дозволяє запобігти розвитку дихальної недостатності.

Ключові слова: дихальна недостатність; неінвазивна вентиляція; онкологія; гіпоксія.

\title{
EXPERIENCE WITH THE USE OF NONINVASIVE VENTILATION IN CANCER PATIENTS AFTER LOBECTOMY
}

\section{N. V. Krasnoselskyi ${ }^{1}$, E. N. Krut ${ }^{\prime} o^{1}$, O. N. Yurchenko ${ }^{1}$, A. A. Halushko² (Kharkiv, Kiev; Ukraine)}
${ }^{1}$ Grigoriev Institute of Medical Radiology of National Academy of Medical Science of Ukraine; ${ }^{2}$ Shupyk National Medical Academy of Postgraduate Education

With the appearance of the modern devices for noninvasive ventilation (NIAVL) in our country, the interest to this issue has increased even more, because the use of a simple, atraumatic method of ventilation allows to avoid intubation and of invasive mechanical ventilation through an endotracheal tube with their complications for some patients. The purpose of the study was to investigate the effectiveness and indications for the use of noninvasive ventilation in cancer patients which underwent surgical operations on the thoracic organs. Since 2013, 34 patients who underwent surgical treatment on the thoracic organs have been examined. Patients were divided into two groups. The first group included patients $(n=24)$, which received noninvasive lung ventilation (NIAVL) in the early postoperative period. The second group consisted of patients $(n=10)$ that were treated according to the local protocol. The use of NIAVL in patients that were operated on the chest organs proved to be effective as it improved hemodynamics and blood gases balance and it can prevent the development of respiratory failure.

Key words: respiratory failure; noninvasive ventilation; cancer; hypoxia.

O. S. KHUKHLINA, O. O. URSUL, I. V. DUDKA, K. V. VILIGORSKA, L. V. KANIOVSKA, V. S. GAIDYCHUK, O. S. VOEVIDKA, S. V. KOVALENKO (Chernivci, Ukraine)

\section{IMPACT OF SMOKING ON THE MAIN PATHOGENETIC LINKS OF COMORBID COURSE OF CHRONIC OBSTRUCTIVE PULMONARY DISEASE AND CHRONIC PANCREATITIS}

\author{
HSEE of Ukraine "Bukovinian State Medical University" < oksanakhukhlina@gmail.com>
}

In the result of the study examined 79 patients, among them 30 patients with isolated course of COPD, stage IIB, 22 patients with COPD, stage IIB with comorbid CP in exacerbation phase, 27 patients with isolated course of CP. Smoking impacts deprivation of CFTR function, which regulates chlorine ions transport through chorine channel, localized in the epithelial cells of exocrine glands. The inhibition of the functioning of the chloride channel leads to thickening of the exocrine glands secret that results in its poor evacuation and then obstruction with fibrosis in the organs, such as lungs, liver, gallbladder, pancreas. That why tobacco smoking may be a risk factor for development not only COPD, but also $C P$.

Key words: chronic obstructive pulmonary disease, chronic pancreatitis; alpha1-antitrypsin (A1AT); Cystic Fibrosis Transmembrane Conductance Regulator (CFTR). 
Introduction. Chronic obstructive pulmonary disease (COPD) continues to stay one of the main reasons of morbidity and is on the 4-th place among leading chronic pathologies with a high mortality rate. According to the expert data, up to 2020 it will take the 3-rd place, because nowadays, COPD incidence is increasing. [GOLD 2015]. From $8 \%$ to $20 \%$ of adult patients in the age of 40 and older have COPD [9]. COPD incidence in Ukraine is 3,5-4,2\% of adult population [11].

Substantial widespread incidence of the COPD, progressively increasing number of patients with this pathology, long-term recurrent course, the age of patients (middle and older) are the conditions for comorbid pathologies, and chronic pancreatitis (CP) in particular $[1,5]$. Up to date, researchers from different countries marked a significant incidence of acute pancreatitis (more than 1.5 times) with its transformation into chronic form in 15-30\% of cases [3, 6, 7]. According to research data in Ukraine the incidence of disorders of the pancreas in 2012 was 226 cases per 100000 of population, the prevalence was 2471 per 100000 of population [10].

The main provocative factor of COPD is a long-term smoking (10-20 pack-years) [9]. According the WHO data in 2013 there were 1 milliard smokers in the world. Also, the connection between smoking and the development of chronic pancreatitis in patients with COPD and alcohol abuse was confirmed by some European researchers $[16,18]$. But recently the fact that smoking is an independent factor for the development of chronic or acute pancreatitis was revealed. Also there is an influence of smoking on bicarbonates and water secretion by exocrine acinar cells, oxidative stress induction and the elevated level of pancreatic calcification. [9, 10, 18]. Negative impact of smoking on alpha1-antitrypsin (A1AT) level, which is a strong proteinases inhibitor and protects the tissues from the disruptive influence of neutrophil elastase, was found $[2,4,8,13,17]$.

The negative impact of smoking on Cystic Fibrosis Transmembrane Conductance Regulator (CFTR) that functions as a channel across the membrane of cells which produces mucus, sweat, saliva, tears, and digestive enzymes is confirmed. The channel transports negatively charged particles called chloride ions into and out of cells [5]. The inhibition of the functioning of the chloride channel leads to thickening of the exocrine glands secret that results in its poor evacuation and then obstruction with fibrosis in the organs, such as lung and the pancreas. (A. Harris, 1993). CFTR localizes in the epithelial cells and regulates exocrine function of lungs, liver, gallbladder, pancreas and sweat glands [14, 19].

Considering that the "gold" standard of diagnosis in function violation of CFTR is the analysis of ion concentration (mainly chlorine ions) of the sweat with the help of test with pylocarpinum (sweat test) we studied the likability of the influence of smoking on chlorine channel function in patients with comorbid COPD and CP and its impact on serum level of A1AT.

The aim - to investigate the influence of smoking on TP function and serum concentration of A1AT in patients with comorbid course of COPD and CP.

Material and methods. We examined 79 patients, among them 30 (38\%) patients with isolated course of COPD, stage IIB (1-st group), $22(27,8 \%)$ patients with COPD, stage IIB with comorbid CP in exacerbation phase (2-nd group), 27 (34,2\%) patients with isolated course of CP (3-rd group). The sex prevalence was in male patients: 46 male patients $(58,2 \%)$ and 33 female patients $(41,8 \%)$. The mean age was $(54,8 \pm 5,9)$ years old. The informed consent was obtained from all patients involved in the study.

The inclusion criteria for the patients were according the severity of the COPD course. COPD was diagnosed according to the clinical protocol approved by the Ministry of Health of Ukraine № № 555 (06.27.2013) and GOLD 2013. CP was diagnosed according to the clinical protocol approved by Ministry of Health of Ukraine № № 638 (10.09.2014) and clinical symptoms: pain, dyspepsia, exocrine pancreatic insufficiency, ultrasound (US) of the pancreas. 
Control group (CG) consisted of 12 practically healthy individuals (PHI), age $(52,8 \pm 10,4)$ years old, male $-5(41,7 \%)$, female $-7(58,3 \%)$ who at the moment of the study had no chronic or acute pathology.

Exclusion criteria were the following diseases: bronchial asthma, severe cardiovascular pathology (IHD, CHF IIA, IIB,III, HHD I-IIIrd stage, cardiomyopathy, rheumatic heart disease), connective tissue diseases like systemic lupus, scleroderma, polymyositis, oncological diseases, tuberculosis, occupational diseases, acute and chronic cholecystitis, hepatitis, ulcers in the gastrointestinal tract, renal pathology.

For the evaluation of the symptoms all patients with COPD were asked to fill-in Modified Medical Research Council scale (mMRC) and they underwent COPD Assessment Test (CAT). The mMRC scale showed only one symptom - dyspnea, while CAT shows us the influence of COPD on patient's quality of life in more detailed manner. Smoking history was evaluated by calculating the "pack-years" index.

The complex ultrasonography (US) of the pancreas was done with AU-4 Idea" (Biomedica, Italy) convex sonde at a rate 3,5 MHz. We estimated the size, density and echostructrure of the pancreas parenchyma, Wirsung duct dilatation and the state of its walls.

The pulmonary function test (PFT) was done with computer spirometry on spirometer "Microlab-3300" ("Sensor - Medics", Netherlands). According to COPD recommendations for diagnosis, FEV $1<80 \%$ and FEV1/FVC $<70 \%$ were the signs of not fully reversible obstruction. To test the reversibility of bronchial obstruction we used inhalation of $\beta$-agonist (salbutamol, $400 \mathrm{mcg}$ ). In all patients PFT indices were estimated after bronchodilator administration (approximately 15 minutes after). FEV1 increasing rate was not more than $15 \%$ or $200 \mathrm{ml}$.

For the definition of chlorine ions concentration in the sweat we used L. E. Gibson, R. E. Cooke (1959) method: "A test for concentration of electrolytes in sweat in cystic fibrosis of the pancreas utilizing pilocarpine by iontophoresis". Sweating was induced by pilocarpine iontophoresis on the forearm. The positive result was estimated as $>60 \mathrm{mmol} / \mathrm{l}$, with the marginal level $40-60 \mathrm{mmol} / \mathrm{l}$ and negative result was estimated as $<40 \mathrm{mmol} / \mathrm{l}$. The A1AT level in blood serum was estimated by enzyme-linked immunosorbent assay, ELISA test by Immundiagnostik (Germany).

The results were calculated in «Statistica for Windows 6.0» with the use of statistical significant parametric and nonparametric criteria.

Results and discussion. During our research all patients with COPD of the II-nd stage according to clinical symptoms estimation, function and complication evaluation were diagnosed as clinical group B according to GOLD. The main complaint was expiratory dyspnea (100\% of all patients) that appeared during even minimal physical effort and at night. All patients were complaining on dry cough $(8,9 \%)$ and productive cough with mucous $(46,7 \%)$ or purulent sputum $(44,4 \%)$. During physical examination in patients with isolated COPD course the dilatation of intercostal space was found, the apex of the lungs showed higher $V / Q$ ratio and lower position of diaphragm, deviation in percussion, tachypnea, auscultation - rhonchi, extended exhalation. In comorbidity of COPD and CP we noted abdominal bloating due to meteorism.

From 79 patients - 46 patients were smokers $(58,2 \%)$, pack-year index was $(21,07 \pm$ $11,45)$. From 30 patients of the $1^{\text {st }}$ group $-14(46,7 \%)$ were smokers, in the $2^{\text {nd }}$ group, from 22 patients $-15(68,2 \%)$ and 13 patients $(48,1 \%)$ from the 27 patients of the 3 -rd group. The highest percentage of patients who were smokers we can note in the 2-nd group, the group with comorbid COPD and CP course.

The results of mean indices of chlorine ions in sweat in comparison with the results in the group of practically healthy individuals were the following: in the 1-st group $(22,0 \pm 6,6) \mathrm{mmol} / \mathrm{l}(\mathrm{P}>0,05)$, in the 2-nd group $(54,4 \pm 6,1) \mathrm{mmol} / 1(\mathrm{P}<0,05), 3$-rd group $(30,0 \pm 17,3) \mathrm{mmol} / \mathrm{l}(\mathrm{P}>0,05)$, and in the control group $(20,22 \pm 5,20) \mathrm{mmol} / \mathrm{l}$, with the likely intra-group difference in indices of the 1 -st and the 2 -nd group $(\mathrm{P}<0,05)$. 
Statistically significant rise of chlorine ions in sweat was detected in the 2-nd group. This can be connected with the negative influence of smoking on chlorine channel. In 1983 Michael Welsh on the animal model of dog trachea showed that tobacco smoke deprives ion transport and suggested that this fact can explain pathological mucociliary clearance of respiratory tract that is present in smokers [20]. Cantin et al., investigated the effect of tobacco smoke on human respiratory tract epithelium and showed that chlorine channel function reduces under smoke, the glands start producing thick bronchial secret which results in poor mucociliary clearance [12]. This phenomena was called chronic bronchitis or "smoker's lung". M. T. Dransfeld et al. [15], confirmed the existence of CFTR dysfunction in the lungs that manifests as pathological chlorine transport in patients with COPD or smokers. CFTR is localized in the epithelium cells of the pancreas and encodes chlorine channel function. According to that we may suggest that there are pathological secretion in the pancreas that explains frequent comorbid course or intra-development of COPD and CP in patients who smoke.

Recently, the dependence between smoking and blood serum level of A1AT was found, that was proved by many Ukrainian and international researchers $[2,4,8,13]$. A1AT is also called A1- proteinase inhibitor because it inhibits the activity of numerous proteinases making the protection of the tissues and cells, in particular from their enzymatic action. For example, in chronic inflammation process A1AT has protective action against neutrophil elastase that ruins lung elastin in COPD. Tobacco smoke oxidizes methionine residue of A1AT that is responsible for elastin binding, that leads to emphysema progression. Taking into account the facts that are mentioned above, we investigated the blood serum level A1AT in patients with isolated COPD course and in patients with COPD and comorbid $\mathrm{CP}$, depending on the presence of provoking factor, such as smoking.

We examined 50 patients, 30 male $(60 \%)$, 20 female $(40 \%)$.The mean age was $(61,2 \pm 9,8)$ years old. The patients were divided into 2 groups: in the 1-st group were 21 patients with isolated COPD course, stage II B (42\%), 2-nd group: 29 patients $(58 \%)$ with COPD, stage II B and comorbid CP in the exacerbation phase. The control group included 10 practically healthy individuals of corresponding age and sex without any chronic pathology.

Mean indices of A1AT in blood of the patients of the 1-st group were $(1,39 \pm$ $0,05) \mathrm{g} / 1(\mathrm{P}<0,05), 2$-nd - $(1,54 \pm 0,09) \mathrm{g} / 1(\mathrm{P}>0,05)$, while in the control group $(1,72 \pm 0,10) \mathrm{g} / \mathrm{l}$. It should be noted, that blood serum levels of A1AT in all groups of patients that were involved into research were in normal ranges $(0,9-2) \mathrm{g} / \mathrm{l}$. The difference between A1AT levels in patients who were smokers and non-smokers was the following: in the 1-st group starting point from $61,9 \%$ and $(1,25 \pm 0,05) \mathrm{g} / 1(\mathrm{P}<0,05)$ up to $38,1 \%$ and $(1,60 \pm 0,09) \mathrm{g} / 1(\mathrm{P}<0,05)$, in the 2 -nd group 55,2 \% $-(1,27 \pm$ $0,03) \mathrm{g} / 1(\mathrm{P}<0,05)$ up to $44,8 \%-(1,88 \pm 0,07) \mathrm{g} / 1(\mathrm{P}<0,05)$, while in control group $40 \%-(1,63 \pm 0,06) \mathrm{g} / \mathrm{l}$ up to $60 \%-(1,79 \pm 0,06) \mathrm{g} / 1(\mathrm{P}>0,05)$. Therefore, we can detect that the highest percentage of smokers is in the 1-st group, that coincides with low levels of A1AT in the same group. So, the preliminary conclusion might be done smoking can be a risk factor that inhibits a normal production of A1AT.

Conclusions. 1. Smoking impacts deprivation of CFTR function, which regulates chlorine ions transport through chorine channel, localized in the epithelial cells of exocrine glands. This manifests in thickening of the gland secret that worsens COPD and CP comorbid course. 2. Tobacco smoking may be a risk factor for development not only COPD or other respiratory problems, but also $\mathrm{CP}$ which, according to the results of our research inhibits normal production A1AT in the group with comorbid COPD and CP.

Prospect for further research is studying of genetic factors that may contribute to pathogenesis of mutual burdening syndrome of COPD and CP. 


\section{$\mathrm{R}$ e f e r e n c e s}

1. Бабінец̧ь Л. С., Квасніи̧ька О. С., Крисків O. I. та ін. Супутнє хронічне обструктивне захворювання легень як предиктор ускладнення клінічного перебігу та зниження якості життя при хронічному панкреатиті // Буковин. мед. вісн. - 2011. Т.15, Вип. 59, № 3. - С. 153-156.

2. Болокадзе С. О. Особливості діагностики та прогнозування перебігу ХОЗЛ на сучасному етапі // Медицина сьогодні і завтра. - 2014. - Вип. 62, № 1. - С. 59-62.

3. Губергрии Н. Б., Христич Т. Н.. Клиническая панкреатология. - Донецк: ООО «Лебедь», 2000. - 416 с.

4. Дорофєєв А. Е., Хоростовська-Винімко Й., Чуков $A$. Б. та ін. Тяжкість перебігу хронічних обструктивних захворювань легень у пацієнтів Донецького регіону залежно від генотипічних та фенотипічних чинників ризику // Медицина транспорту України. - 2013. - № 2. - С. 17-22.

5. Железнякова Н. М., Пасієшвілі Т. М. Особливості клінічної маніфестації хронічного обструктивного захворювання легень у хворих на хронічний панкреатит // Семейная медицина. - 2015. - Вип. 62, № 6. - С. 60-72.

6. Калинин A. В. Хронический панкреатит: распространенность, этиология, патогенез, классификация и клиническая характеристика этиологических форм (сообщение первое) // Клин. перспективы гастроэнтерол., гепатол. - 2006. - № 6. - С. 5-15.

7. Маев И. В., Казюлин А. Н., Кучерявый Ю. А. Хронический панкреатит. - М.: Медицина, 2005. - 540 c.

8. Периева Т. О., Гашинова К. Ю., Віклієнко Ю. І. ХОЗЛ: рівень ААТ у сироватці крові та частота загострень захворювання // Клін. медицина. - 2011. - Т. 16/4. C. 1-4.

9. Уніфікований клінічний протокол первинної, вторинної (спеціалізованої), третинної (високоспеціалізованої) медичної допомоги та медичної реабілітації. Хронічне обструктивне захворювання легень. Наказ МО3 України від 27.06.2013 р. № 555.

10. Уніфікований клінічний протокол первинної, вторинної (спеціалізованої) медичної допомоги та медичної реабілітації. Хронічний панкреатит. Наказ МО3 України від 10.09.2014 р. № 638 .

11. Фещченко Ю. И. Хроническое обструктивное заболевание лёгких - актуальная медико-социальная проблема // Укр. пульмонол. журн. - 2011. - № 2. - С. 6-7.

12. Cantin A. M., Hanrahan J. W., Bilodeau G. et al. Cystic fibrosis transmembrane conductance regulator function is suppressed in cigarette smokers // Am. J. Respir. Crit. Care Med. - 2006. Vol. 173.- P. 1139-1144.
1. Babinec'L. S., Kvasnic'ka O. S., Kriskiv O.I. ta in. Suputne hronichne obstruktivne zahvoryuvannya legen' yak prediktor uskladnennya klinichnogo perebigu ta znizhennya yakosti zhittya pri hronichnomu pankreatiti // Bukovin. med. visn. - 2011. T.15, Vip. 59, № 3. - S. 153-156.

2. Bolokadze E. O. Osoblivosti diagnostiki ta prognozuvannya perebigu HOZL na suchasnomu etapi // Medicina s'ogodni i zavtra. 2014. - Vip. 62, № 1. - S. 59-62.

3. Gubergric N. B., Hristich T. N. Klinicheskaya pankreatologiya. - Doneck: OOO «Lebed'», 2000. - $416 \mathrm{~s}$.

4. Dorofecv A. E., Horostovs'ka-Vinimko J., Chukov A. B. ta in. Tyazhkist' perebigu hronichnih obstruktivnih zahvoryuvan' legen' u pacientiv Donec'kogo regionu zalezhno vid genotipichnih ta fenotipichnih chinnikiv riziku // Medicina transportu Ukraïni. - 2013. - № 2. - S. 17-22.

5. Zheleznyakova N. M., Pasieshvili T. M. Osoblivosti klinichnoï manifestaciï hronichnogo obstruktivnogo zahvoryuvannya legen' u hvorih na hronichnij pankreatit // Semejnaya medicina. - 2015. - Vip. 62, № 6. - S. 6072.

6. Kalinin A. V. Hronicheskij pankreatit: rasprostranennost', ehtiologiya, patogenez, klassifikaciya i klinicheskaya harakteristika ehtiologicheskih form (soobshchenie pervoe) // Klin. perspektivy gastroehnterol., gepatol. 2006. - № 6. - S. 5-15.

7. MaevI. V., Kazyulin A. N., Kucheryavyj Yu.A. Hronicheskij pankreatit. - M.: Medicina, 2005. $-540 \mathrm{~s}$.

8. Perceva T. O., Gashinova K. Yu., Viklienko Yu. I. HOZL: riven' AAT u sirovatci krovi ta chastota zagostren' zahvoryuvannya // Klin. medicina. -2011. - T. 16/4. - S. 1-4.

9. Unifikovanij klinichnij protokol pervinnoï, vtorinnoï (specializovanoï), tretinnoï (visokospecializovanoï) medichnoï dopomogi ta medichnoï reabilitaciï. Hronichne obstruktivne zahvoryuvannya legen'. Nakaz MOZ Ukraïni vid 27.06.2013 r. № 555.

10. Unifikovanij klinichnij protokol pervinnoï, vtorinnoï (specializovanoï) medichnoï dopomogi ta medichnoï reabilitaciï. Hronichnij pankreatit. Nakaz MOZ Ukraïni vid 10.09 .2014 r. № 638.

11. Feshchenko Yu. I. Hronicheskoe obstruktivnoe zabolevanie legkih - aktual'naya mediko-social'naya problema // Ukr. pul'monol. zhurn. -2011 . - № 2. - S. 6-7. 
13. Chotirmall S. H., Alawi M. A., Enery T. M. et al. Alpha-1 protienase inhibitors for the treatment of alpha-1 antitrypsin deficiency: safety, tolerability, and patient outcomes // Therapeutics and clinical risk management. - 2015. - N 11. - P. 143-151.

14. Courville C. A., Tidwell S., Liu B. et al. Acquired defects in CFTR-dependent $\beta$-adrenergic sweat secretion in chronic obstructive pulmonary disease // Respiratory Research. - 2014. - Vol.15, N 1. - P. 15-25.

15. Dransfield M. T., Wilhelm A. M., Flanagan B. et al Acquired cystic fibrosis transmembrane conductance regulator dysfunction in the lower airways in COPD // CHEST. - 2013. - Vol. 144, N 2. - P. 498-506.

16. Haritha J., Wilcox C. M. Evaluation of patients knowledge regarding smoking and chronic pancreatitis. A pilot study // J. Gastroenterol. Pancreatol. Liver Disord. - 2015. - N 1. - P. 1-4.

17. Janciaus S. M., Bals R., Koczulla R. et al. The discovery of alpha-1 antitrypsin and its role in health and disease // Respiratory med. - 2011. - Vol. 105. - P. 1129-1139.

18. Kadiyala V., Lee L. S., Banks P. et al. Cigarette smoking impairs pancreatic duct cell bicarbonate secretion // J. of the pancreas. - 2013. - Vol. 14, N 1. - P. 31-38.

19. Rab A., Rowe S. M., Raju S. V. Cigarette smoke and CFTR: implications in the pathogenesis of COPD // Am. J. Physiol. Lund Cell. Mol. Physiol. - 2013. - Vol. 305. - P. 530-541.

20. Welsh M. J., Smith A. E. Molecular mechanisms of CFTR chloride channel dysfunction in cystic fibrosis // CELL. - 1993. - Vol. 73. - P. 1251-1254.

\title{
ВПЛИВ КУРІННЯ НА ОСНОВНІ ПАТОГЕНЕТИЧНІ ЛАНКИ КОМОРБІДНОГО ПЕРЕБІГУ ХРОНІЧНОГО ОБСТРУКТИВНОГО ЗАХВОРЮВАННЯ ЛЕГЕНЬ ТА ХРОНІЧНОГО ПАНКРЕАТИТУ
}

\author{
О. С. Хухліна, О. О. Урсул, І. В. Дудка, К. В. Вілігорська, Л. В. Каньовська, В. С. Гайдичук, \\ О. С. Воєвідка, С. В. Коваленко (Чернівці)
}

Обстежено 79 хворих, серед яких 30 з ізольованим перебігом хронічного обструктивного захворювання легень (ХОЗЛ) IIВ у фазі неінфекційного загострення і 22 хворих на ХОЗЛ ІІВ у фазі неінфекційного загострення та супровідним ХП у фазі помірного загострення, 27 хворих з ізольованим перебігом ХП у фазі загострення. Виявлено пригнічення функції трансмембранного регуляторного білка муковісцидозу (ТРБМ) під впливом тютюнового диму, який функціонує як цАМФзалежний хлоридний канал, та відповідальний за транспорт іонів хлору, натрію і бікарбонатів. Пригнічення функції хлоридного каналу призводить до згущення секрету екзокринних залоз та порушення його евакуації, що викликає прогресування обструкції й фіброзу в ушкоджених органах. ТРБМ локалізується в епітеліальних клітинах легень, печінки, жовчного міхура, підшлункової залози. Тому куріння можна розглядати як фактор ризику розвитку не тільки ХОЗЛ, але і ХП.

Ключові слова: хронічне обструктивне захворювання легень; хронічний панкреатит; $\alpha 1$ антитрипсин (А1АТ); трансмембранний регуляторний білок муковісцидозу.

\section{ВЛИЯНИЕ КУРЕНИЯ НА ОСНОВНЫЕ ПАТОГЕНЕТИЧЕСКИЕ ЗВЕНЬЯ КОМОРБИДНОГО ТЕЧЕНИЯ ХРОНИЧЕСКОЙ ОБСТРУКТИВНОЙ БОЛЕЗНИ ЛЁГКИХ И ХРОНИЧЕСКОГО ПАНКРЕАТИТА}

\section{О. С. Хухлина, О. А. Урсул, И. В. Дудка, К. В. Вилигорская, Л. В. Каневская, В. С. Гайдичук,} А. С. Воевидка, С. В. Коваленко (Черновцы)

В результате проведённого исследования обследовано 79 больных, среди которых 30 больных с изолированным течением хронической обструктивной болезни лёгких (ХОБЛ) IIB в фазе неинфекционного обострения, 22 больных ХОБЛ IIB, в фазе неинфекционного обострения и сопутствующим ХП в фазе умеренного обострения, 27 больныХ с изолированным течением ХП в фазе обострения. Выявлено угнетение трансмембранного регуляторного белка муковисцидоза (ТРБМ) под влиянием табачного дыма, который функционирует как цАМФ-зависимый хлоридный канал, и ответственный за транспорт ионов хлора, натрия и бикарбонатов. Угнетение хлоридного канала приводит к сгущению секрета экзокринных желёз и нарушению его эвакуации, что вызывает прогрессирование обструкции и фиброза в органах и тканях. ТРБМ локализуется в эпителиальных клетках лёгких, печени, жёлчного пузыря, поджелудочной железы. Поэтому курение можно рассматривать как фактор риска развития не только ХОБЛ, но и ХП.

Ключевые слова: хроническая обструктивная болезнь лёгких; хронический панкреатит; $\alpha 1$-антитрипсин (А1АТ); трансмембранный регуляторный белок муковисцидоза. 